\title{
Field Efficacy of Bio-fertilizers and Bio-inputs to Improve Wheat (Triticum aestivum) Production under Alkaline Soil in Kachchh District of Gujarat
}

\author{
M.H. Trivedi ${ }^{1 *}$, M. Ahir ${ }^{2}$, S. Vyas ${ }^{2}$, and H.B. Singh ${ }^{3}$ \\ ${ }^{1}$ Department of Earth and Environmental Science, KSKV Kachchh University, Mundra Road, Bhuj - 01, Kachchh, Gujarat, India \\ ${ }^{2}$ Satvik, Promoting Organic Farming, Bhuj - 01, Kachchh, Gujarat, India \\ ${ }^{3}$ Somvanti Research Foundation, 13/21 Vikas Nagar, Lucknow-226022, India
}

*Corresponding author: drmrugesh.trivedi@gmail.com (ORCID ID: 0000-0001-6159-4402)

Paper No. 865

Received: 25-07-2020

Revised: $13-10-2020$

Accepted: 29-11-2020

\begin{abstract}
With the aim of reducing chemical fertilizer application and improving the sustainability of wheat cultivation under alkaline soil, the present study investigated the effects of different biofertilizers and organic products on wheat productivity. The application of these products was applied in the soil through irrigation water as solitary or in consortia by three different ways of treatment, i.e. (1) single treatment; (2) double treatment (first and 21 days), and (3) triple treatment (first, 21 days and 45 days). We demonstrate that all the biofertilizers significantly enhanced wheat productivity as compared to the control treatment, but this was mostly observed with more than one treatment condition. The biofertilizers were applied in solitary and consortia treatments. Solitary treatment of Azospirillium spp, Bacillus subtilis, and Pseudomonas fluorescence was found effective. However, the Nitrogen consortium treatment of biofertilizers (Azotobacter chroococcum + Azospirillium spp) was more prominent as compared to solitary application. Our results suggest that more than one application of biofertilizers may be effectively exploited for sustainable wheat production in an eco-friendly way, but attention should be paid to the consortium approach or organic amendments during cultivation.

Highlights

( B Bioinoculant showed a positive effect due to their PGP characteristics on wheat shoot growth

o Promising bacterial strains of Nitrogen fixers have potential as inoculation agents in eco-friendly wheat crop production under abiotic stress contributing to environmental sustainability.
\end{abstract}

Keywords: Alkaline soil, biofertilizers, organic farming, wheat production

Wheat (Triticum aestivum L.) is one of the largest growing cereal crops worldwide. This cereal crop plays a major role in fulfilling the increased demand for food to ensure food security. Fertilization is a main driving force in wheat cultivation to increase grain yield and quality (Zhang et al. 2014; Mon et al. 2016). For this, farmers applied a large dose of chemical fertilizers to improve the production of wheat. However, irregular use of chemical fertilizers and pesticides negatively impacts on the environment, including soil fertility, microbial diversity, water holding capacity, nutrient mobilization capacity, etc. (Xiao et al. 2019). In recent decades, agricultural scientists devoted their research towards organic farming and emphasized the use of organic manure, biofertilizers, biopesticides, and other organic amendments in cultivation practices to improve plant productivity (Abou-Aly et al. 2009; Rakshit et al. 2014; Cisse et al. 2019; Cortivo et al. 2020; Sarkar et al. 2020).

How to cite this article: Trivedi, M.H., Ahir, M., Vyas, S. and Singh H.B. 2020. Field Efficacy of Bio-fertilizers and Bio-inputs to Improve Wheat (Triticum aestivum) Production under Alkaline Soil in Kachchh District of Gujarat. IJAEB, 13(4): 431-437.

Source of Support: None; Conflict of Interest: None 
A long term organic farming practices showed positive impacts on soil fertility, dry crop matter, grain yield, and nutritional value (Esmailpour et al. 2013). Application of organic fertilizers and biofertilizers help wheat plants to survive under abiotic and biotic stress conditions (Mahmoud et al. 2008; Dal Cortivo et al. 2020). Hence, the microbial intervention has great potential to improve plant productivity under adverse conditions also and reduce the dependency on chemical fertilizers (Kumar et al. 2017; Manjhi et al. 2016; Parihar and Rakshit 2016). In the presented study, we conducted different experiments with biofertilizers, and nutrient compounds to evaluate their effect on wheat productivity.

The Kachchh area of Gujarat, India is highly alkaline with more than $89 \%$ villages having $\mathrm{pH}$ more than 8 , Organic content $<1$, and deprived with nitrogen $(\mathrm{N})$ content the main requirement for wheat growth (Un published report of Satvik, 2016). In addition, the alkaline nature would further reduce the availability of other nutrients like $\mathrm{P}, \mathrm{Fe}, \mathrm{Zn}$ for plants. Hence, the aims of the present study were designed to improve wheat productivity and nutritional quality growing in the soil of the Kachchh region through organic farming practices by applying different amendments including dung water, curd, rock phosphate, and different commercially available biofertilizers alone and in different combinations. To attempt this objective, experiments were designed with different nutrient solubilizing microbes i.e., a nitrogen fixer, phosphate solubilizer, potassium solubilizer, Arbuscular mycorrhize fungi, and bio-control fungi Trichoderma. The effect of these microbes on wheat productivity was also compared with other organic treatments such as dung water, curd water, and chemical fertilization.

\section{MATERIALS AND METHODS}

\section{Study Area}

Experiments were conducted in the Anjar region of Gujarat, India. The geographical location of the farm is 23.134143" N (latitude), 69.898209" E (longitude). The farm is a certified organic farm (certificate no. ORG/SC/1312/001634) with NPOP, EU, and NOP standards by IMO Control Pvt. Ltd (Fig. 1).

\section{Treatments}

- To get a sustainable source of nitrogen - mix plantation strategy with Ranjako (Medicago sativa) and leguminous crops (Cicer arietinum) as compared to alone and different combinations of $\mathrm{N}$ fixing bio-fertilizer like Azotobacter chroococcum, Acetobacter diazotrophicus and Azospirillium spp. were used.

- To get a sustainable source of phosphorous, application of rock phosphate alone as compared to the application of bio-fertilizer like Pseudomonas fluorescens and Bacillus subtilis as well as in the combination of rock phosphate and Pseudomonas fluorescens were used.

- Impact of application of Potash solubilizing bacteria (Fraturia aurantia) in high Potash (K) soil of Kachchh on wheat productivity were studied.

- Application of micronutrients (Fe 60\%, Zn 20\%, Mn $10 \%, \operatorname{Mg} 10 \%$ ) on wheat productivity were also studied.

- Application of fungus like Trichoderma harzianum (In addition to anti-fungal activity, the genus boosts germination rate, solubilizes various insoluble forms of phosphates, augments nitrogen fixation)

- Arbuscular mycorrhizal Fungi (Increases the uptake and mobilization nutrients) on wheat production were also studied.

The farm covered total of 20 Acres $\left(80,000 \mathrm{~m}^{2}\right)$ of land. Out of which approximately $3,900 \mathrm{~m}^{2}$ area was occupied for the present investigation and divided into 52 plots, each of $25 \mathrm{~m}^{2}$ as shown in Fig. A. As per standard criteria, $0.5 \mathrm{~m}$ border area was eliminated from each plot for the calculation of production of the crop during harvesting to avoid cross-contamination of application of amendments by adjoining plots. Therefore, production occurred in $13.50 \mathrm{~m}^{2}$ area was considered as the production of wheat in each plot. A total of twenty amendments was applied (including control). The details of the amendments, dose, and their application are given in table 1. The method of irrigation used was Check Basin (CB). The farmers were well trained for the uniform application of each amendment in each plot using CB method of irrigation. The seeds were sowed by Automatic Seed Drill along with a tractor. The date of Seed sowed was 22.11.2019, and the date of crop harvested was 30.03.2020.

The treatment was divided into three types, viz. T1 
Table 1: Details of study design

\begin{tabular}{|c|c|c|c|c|}
\hline $\begin{array}{l}\text { Code } \\
\text { No. }\end{array}$ & Amendments & $\begin{array}{l}\text { No. of } \\
\text { Applications/ } \\
\text { Treatment }\end{array}$ & No. of plots & Dose (for $25 \mathrm{~m}^{2}$ plot) \\
\hline 1 & Soil & Control & Single & No Treatment \\
\hline 2 & $\begin{array}{l}\text { Wheat + Ranjko (Medicago } \\
\text { sativa) }\end{array}$ & Mix Crop & Single & \multirow{2}{*}{$\begin{array}{l}\text { Supplementary (Leguminous) crop for Nitrogen } \\
\text { fixation. } 15 \text { gram Medicago sativa seeds was sown } \\
\text { along with wheat and } 30 \text { gram Cicer arietinum seeds } \\
\text { were sown along with wheat }\end{array}$} \\
\hline 3 & $\begin{array}{l}\text { Wheat }+ \text { Chickpea }(\text { Cicer } \\
\text { arietinum })\end{array}$ & Mix Crop & Single & \\
\hline 4 & $\begin{array}{l}\text { Micro Nutrient }\left(\mathrm{FeSO}_{4}+\right. \\
\left.\mathrm{ZnSO}_{4}+\mathrm{MgSO}_{4}+\mathrm{MnSO}_{4}\right)\end{array}$ & $\mathrm{T} 1, \mathrm{~T} 2, \mathrm{~T} 3$ & Three & $\begin{array}{l}\text { The standard dose for the application of } \\
\text { micronutrient is } 25 \mathrm{Kg} / \text { Acer, and therefore, } 150 \mathrm{gm} \\
\text { was taken for } 25 \mathrm{~m}^{2} \text { plot from a bag containing ( } 15 \\
\mathrm{Kg} \text { of } \mathrm{Fe}, 5 \mathrm{Kg} \text { of } \mathrm{Zn}, 2.5 \mathrm{Kg} \text { of Mn and } 2.5 \mathrm{Kg} \text { of } \mathrm{Mg}) \\
\text { and mixed in } 1 \mathrm{~L} \text { water and applied in the study along } \\
\text { with irrigation water. }\end{array}$ \\
\hline 5 & Dung Water & $\mathrm{T} 1, \mathrm{~T} 2, \mathrm{~T} 3$ & Three & $\begin{array}{l}\text { The standard dose for the application of Gobar water } \\
\text { is } 400 \mathrm{Kg} / \text { Acer and therefore, } 2.5 \mathrm{Kg} \text { of Gobar was } \\
\text { mixed in 10L of water and used for } 25 \mathrm{~m}^{2} \text { plot. The } \\
\text { slurry was filtered and applied in the study, along } \\
\text { with irrigation water. }\end{array}$ \\
\hline 6 & Curd Water & $\mathrm{T} 1, \mathrm{~T} 2, \mathrm{~T} 3$ & Three & $\begin{array}{l}\text { The standard dose for the application of curd is } 20 \\
\mathrm{Kg} / \text { Acer, and therefore, } 125 \mathrm{Gm} \text { of curd was mixed } \\
\text { in } 1 \mathrm{~L} \text { water for } 25 \mathrm{~m}^{2} \text { plot and applied in the study } \\
\text { along with irrigation water. }\end{array}$ \\
\hline 7 & Azotobacter chroococcum & $\mathrm{T} 1, \mathrm{~T} 2, \mathrm{~T} 3$ & Three & \multirow{6}{*}{$\begin{array}{l}\text { The standard counts of microorganisms in } 2 \mathrm{ml} \\
\text { should be } 10^{11} \text { counts. Which should be dilute in } 1 \\
\text { litre water and apply in one acer as recommended by } \\
\text { Company. The calculation was done for } 25 \mathrm{~m}^{2} \text { plot, } \\
\text { based on } 7 \mathrm{ml} \text { of suspension was taken and further } \\
\text { mixed in } 1 \mathrm{~L} \text { water and applied in } 25 \mathrm{~m}^{2} \text { plot along } \\
\text { with irrigation water. }\end{array}$} \\
\hline 8 & Acetobacter diazotrophicus & $\mathrm{T} 1, \mathrm{~T} 2, \mathrm{~T} 3$ & Three & \\
\hline 9 & Azospirillium spp. & $\mathrm{T} 1, \mathrm{~T} 2, \mathrm{~T} 3$ & Three & \\
\hline 10 & Pseudomonas Florescence & $\mathrm{T} 1, \mathrm{~T} 2, \mathrm{~T} 3$ & Three & \\
\hline 11 & Fraturia aurantia & $\mathrm{T} 1, \mathrm{~T} 2, \mathrm{~T} 3$ & Three & \\
\hline 12 & Bacillus subtilis & $\mathrm{T} 1, \mathrm{~T} 2, \mathrm{~T} 3$ & Three & \\
\hline
\end{tabular}

13 Trichoderma harzianum

T1, T2, T3 Three

$14 \quad$ AMF (Arbuscular Mycorrhizal Fungi)

T1, T2, T3 Three plots

The standard counts of microorganism should be 100 gram $\times 3000$ counts/Acer as recommended by Company. The calculation was done for $25 \mathrm{~m}^{2}$ plot, based on $7 \mathrm{ml}$ of suspension was taken, and further mixed in $1 \mathrm{~L}$ water and applied in $25 \mathrm{~m}^{2}$ plot along with irrigation water.

\begin{tabular}{|c|c|c|c|}
\hline 15 & $\begin{array}{l}\text { Azotobacter chroococcum }+ \\
\text { Acetobacter diazotrophicus }\end{array}$ & $\mathrm{T} 1, \mathrm{~T} 2, \mathrm{~T} 3$ & Three \\
\hline 16 & $\begin{array}{l}\text { Azotobacter chroococcum }+ \\
\text { Azospirillium spp }\end{array}$ & $\mathrm{T} 1, \mathrm{~T} 2, \mathrm{~T} 3$ & Three \\
\hline & $\begin{array}{l}\text { Acetobacter diazotrophicus + } \\
\text { Azospirillium spp }\end{array}$ & $\mathrm{T} 1, \mathrm{~T} 2, \mathrm{~T} 3$ & Three \\
\hline & $\begin{array}{l}\text { Azotobacter chroococcum }+ \\
\text { Acetobacter diazotrophicus }+ \\
\text { Azospirillium spp. }\end{array}$ & $\mathrm{T} 1, \mathrm{~T} 2, \mathrm{~T} 3$ & Three \\
\hline & Rock Phosphate (RP) & $\mathrm{T} 1$ & Single \\
\hline
\end{tabular}

$7 \mathrm{ml}$ of each suspension was taken as described above and mixed in $1 \mathrm{~L}$ water, and applied in the study along with irrigation water.

The standard dose for the application of RP is 400 $\mathrm{Kg} /$ Acer therefore, $2.5 \mathrm{Kg}$ of RP was taken for $25 \mathrm{~m}^{2}$ plot. Due to the floating tendency of RP on water, the RP powder was mixed with soil in each plot before irrigation water was applied to avoid uneven distribution. 


$\begin{array}{ll}\text { Rock Phosphate }+ & \text { RP was given Three } \\ \text { Pseudomonas F } & \text { only a single } \\ & \text { time, and } \\ & \text { Pseudomonas F } \\ & \text { was given for T1, } \\ & \text { T2, T3 }\end{array}$

refereed as a single treatment on day one along with irrigation water, T2 referred as two times treatments one was on day one along with irrigation water and second was on 21 days along with irrigation water and T3 refereed as three times treatment one was on day one along with irrigation water, second was on 21 days along with irrigation water and third was on 45 days along with irrigation water. Each plot has received an equal quantity of water and is irrigated on first, 21 , and 45 days.

\section{RESULTS AND DISCUSSION}

The outcome of the study was summarized in table 2. The data were presented as Mean, and S.E. Significant analysis was performed as compared to control using paired student's t test. The result revealed that the application of micronutrients and dung water during T3 treatment was significantly effective at $\mathrm{p}<0.5(4.05 \pm 0.15 \mathrm{~kg} / 5 \mathrm{sq}$. Mt. plot $)$ as compared to control treatment.

The application of Azotobacter chroococcum and Acetobacter diazotrophicus in the solitary application was found to be non-effective during all treatments i.e., T1, T2, and T3. However, the application of Azospirillium spp. in T1 and T2 was found to be significantly effective at $\mathrm{p}<0.5$ as compared to control.

The consortium treatment of Azotobacter chroococcum $\mathcal{E}$ Acetobacter diazotrophicus, and Azotobacter chroococcum \& Azospirillium spp, as well as Acetobacter diazotrophicus \& Azospirillium spp., was found to be significantly effective in T2 and T3 treatment as compared to control at $\mathrm{p}<0.5$. The combination of all three Nitrogen-fixing bacterial species of biofertilizer, i.e., Azotobacter chroococcum, Acetobacter diazotrophicus, and Azospirillium spp. found to be significantly effective in T1, T2, and T3 as compared to control at $\mathrm{p}<0.5$. Treatment of Pseudomonas florescence alone was found to be significantly effective during all treatments i.e., T1, T2, and T3. Treatment of Pseudomonas florescence along with Rock Phosphate was found to be significantly effective during treatment T2 and T3 as compared to control. Treatment of Fraturia aurantia was found to be significantly effective as compared to control at $\mathrm{p}<0.5$ during T1 and T3 treatment. Treatment of Bacillus subtilis was found to be significantly effective at $\mathrm{p}<0.5$ in all treatments i.e., T1, T2, and T3. Treatment of Trichoderma harzianum was found to be significantly effective as compared to control at $\mathrm{p}<0.5$ during T2, while the application of Arbuscular Mycorrhizal Fungi was found to be significant during T3 treatment.

Organic amendments in farming practices are a sustainable approach for improving soil fertility, crop productivity in a cheaper and eco-friendly way. Biofertilizers including bacteria, fungi, cyanobacteria are reported to exert a beneficial impact on the nutritional value and yield of wheat plant (Karthikeyan et al. 2007; Meena et al. 2016; Meena et al. 2017; Cisse et al. 2019; Dal Cortivo et al. 2020). However, most of the studies are performed under laboratory or controlled condition; the positive effect of biofertilizers in open field may constrain due to dynamic environmental conditions. Microbes used in this study Azotobacter chroococcum, Acetobacter diazotrophicus, Azospirillium spp., Pseudomonas florescence, Fraturia aurantia, Bacillus subtilis, Trichoderma harzianum, and Arbuscular mycorrhizal fungi have already been successfully applied on different crops (Wu et al. 2005; Sivasakthivelan et al. 2013; Akladious and Abbas 2014; Wani et al. 2016; Subhashini et al. 2015; Parihar and Rakshit 2016; Parihar et al. 2019; Parihar et al. 2020a and 2020b; Murumkar et al. 2017; Prasad and Babu 2017). In the present study, these microbes were applied as single inoculants and a combination thereof through field application, with the aim to increase the yield of wheat. With these microbial inoculations, we expect nutrient solubilization process in the soil, i.e., potassium and phosphorus, and nitrogen-fixing ability, thereby increasing nutrient uptake efficiency of the plant and finally growth (Mohammadi and Sohrabi 2012; Vaishnav et al. 2013; Itelima et al. 2018). Indeed, more than one-time treatment of these microbial inoculations was found to increase 
Table 2: Impact of the applications of different amendments on wheat production in organic farm (Production in Kg from 13.5 Sq. Mt. Plot)

\begin{tabular}{|c|c|c|c|c|}
\hline Sl. No. & Treatment & T1 & $\mathrm{T} 2$ & T3 \\
\hline 1 & Soil - Control & $3.88 \pm 0.36$ & NA & NA \\
\hline 2 & Wheat + Ranjko (Medicago sativa) & $2.86 \pm 0.34$ & NA & NA \\
\hline 3 & Wheat + Chana (Cicer arietinum) & $3.30 \pm 0.51$ & NA & NA \\
\hline 4 & Rock Phosphate (RP) & $3.78 \pm 0.38$ & NA & NA \\
\hline 5 & Micro Nutrient & $3.88 \pm 0.53$ & $3.85 \pm 0.67$ & $4.05 \pm 0.15^{*}$ \\
\hline 6 & Dung water & $3.72 \pm 0.30$ & $3.89 \pm 0.66$ & $4.00 \pm 0.39^{*}$ \\
\hline 8 & Azotobacter chroococcum & $3.84 \pm 0.31$ & $3.84 \pm 0.68$ & $3.69 \pm 0.50$ \\
\hline 9 & Acetobacter diazotrophicus & $3.86 \pm 0.65$ & $3.70 \pm 0.45$ & $3.57 \pm 0.67$ \\
\hline 10 & Azospirillium spp. & $4.97 \pm 0.09^{*}$ & $3.98 \pm 0.43^{*}$ & $3.80 \pm 0.11$ \\
\hline 11 & Azotobacter chroococcum + Acetobacter diazotrophicus & $3.88 \pm 0.55$ & $3.93 \pm 0.15^{*}$ & $4.06 \pm 0.58^{*}$ \\
\hline 12 & Azotobacter chroococcum + Azospirillium spp & $3.73 \pm 0.33$ & $4.20 \pm 0.14^{*}$ & $4.30 \pm 0.33^{*}$ \\
\hline 17 & Fraturia aurantia & $4.16 \pm 0.17^{*}$ & $3.86 \pm 0.58$ & $4.15 \pm 0.28^{*}$ \\
\hline 18 & Bacillus subtilis & $4.07 \pm 0.53^{*}$ & $4.48 \pm 0.69^{*}$ & $4.01 \pm 0.63^{*}$ \\
\hline 19 & Trichoderma harzianum & $3.55 \pm 0.10$ & $4.08 \pm 0.76^{*}$ & $3.73 \pm 0.84$ \\
\hline 20 & Arbuscular mycorrhizal fungi & $3.53 \pm 0.69$ & $3.68 \pm 0.14$ & $4.15 \pm 0.27^{*}$ \\
\hline
\end{tabular}

* Significant at $p<0.5$ as compared to control using students t-test; Data are expressed as Mean \pm SEM; NA- Not applicable; T1: Single treatment on day 1 along with water; T2: Two times treatment on day 1 and day 21 along with water; T3: Three times treatment on day 1, day 21, and day 45 along with water; 20 tonnes/acre Farm Yard Manure (FYM) application before wheat production.

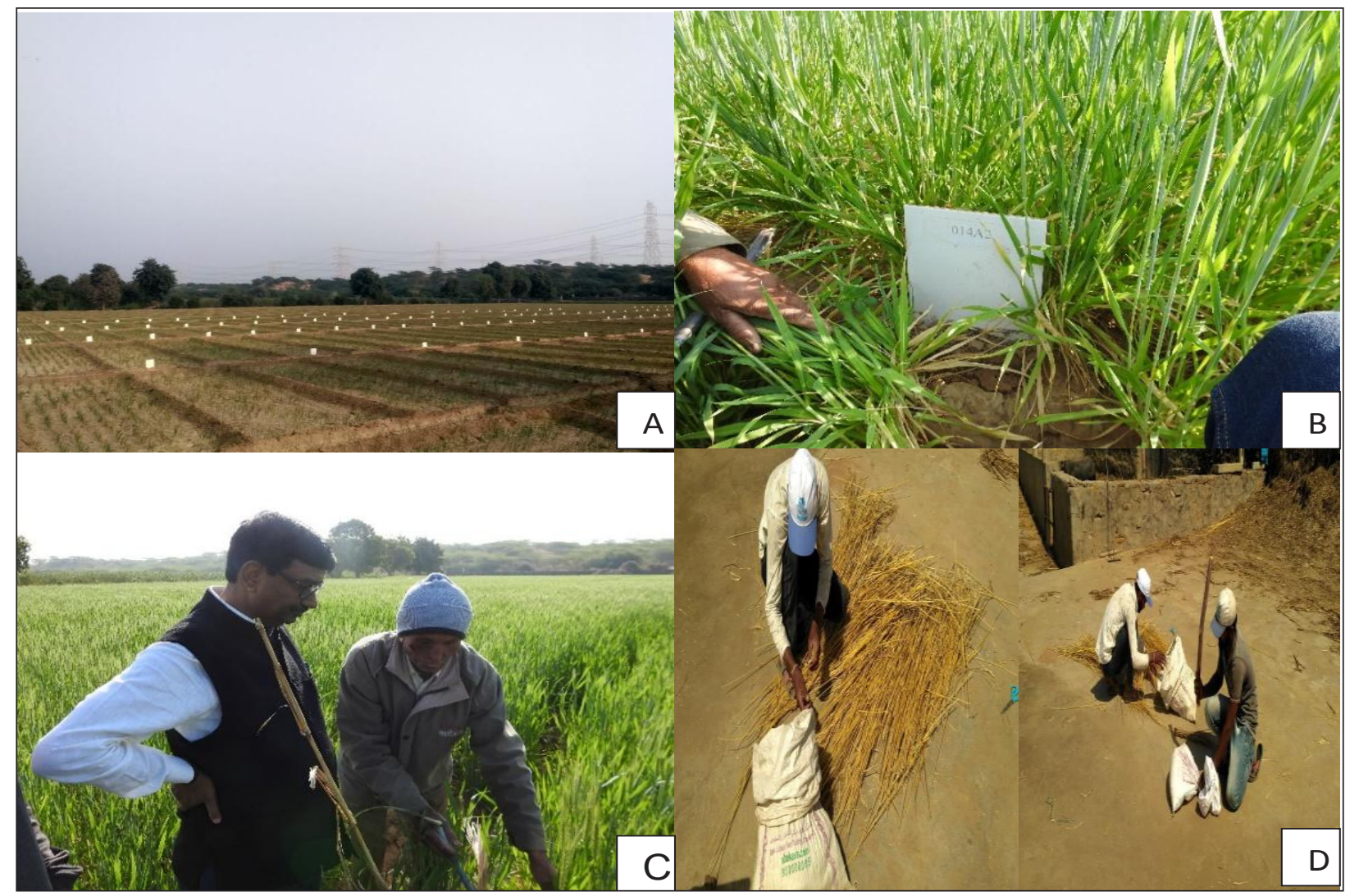

Fig. 1: (A) Plotting in the study area; (B) Systematic labeling of different plots; (C) Monitoring the study and discussion with farmers; (D) Harvesting of the crop on scheduled dates and collection of data 
wheat productivity as compared to the control treatment. The highest productivity was observed with Azospirillium spp. inoculation alone. It might be due to its multiple actions in the soil, like mobilizing the other nutrients as well as maintaining $\mathrm{pH}$ of the soil (Fukami et al. 2018). In consortium treatment, the combined application of Azotobacter chroococcum, Acetobacter diazotrophicus, Azospirillium spp. was found prominent, and it might be due to the role of nitrogen-fixing bacteria in low nitrogen soil of semiarid soil of Kachchh. Rock Phosphate + Pseudomonas treatment was also found to increase productivity as compared to individual treatment that suggests the solubilization of phosphorus by $P$. fluorescence. In addition, we found a clear positive effect of dung water and micronutrient application on wheat productivity as compared to control treatment.

\section{CONCLUSION}

This study has shown that bacteria, fungus, and AMF inoculation have a great impact on wheat plant growth under field conditions. More benefit was observed after three times the application of microbial inoculation. The benefits included the production of wheat gains (in $\mathrm{Kg}$ from 5.00 Sq. Mt. Plot). We confirmed the importance of Nitrogenfixing microbial consortia (Azotobacter chroococcum, Acetobacter diazotrophicus, and Azospirillium spp.) in enhancing wheat growth and productivity. Despite moderate effects, the dung water and curd water tested here are also expected to increase productivity, which is of great importance in organic amendments.

\section{REFERENCES}

Abou-Aly, H.E. and Mady, M.A. 2009. Complemented effect of humic acid and biofertilizers on wheat (Triticum aestivum L.) productivity. Annals of Agric. Sci., Moshtohor, 47(1): 1-12.

Akladious, S.A. and Abbas, S.M. 2014. Application of Trichoderma harzianum T22 as a biofertilizer potential in maize growth. J. Plant Nutri., 37(1): 30-49.

Cisse, A., Arshad, A., Wang, X., Yattara, F. and Hu, Y. 2019. Contrasting impacts of long-term application of biofertilizers and organic manure on grain yield of winter wheat in North China Plain. Agronomy, 9(6): 312.

Dal Cortivo, C., Ferrari, M., Visioli, G., Lauro, M., Fornasier, F., Barion, G., ... and Vamerali, T. 2020. Effects of seed-applied biofertilizers on rhizosphere biodiversity and growth of common wheat (Triticum aestivum L.) in the Field. Frontiers in Plant Science, 11: 72.
Dal Cortivo, C., Ferrari, M., Visioli, G., Lauro, M., Fornasier, F., Barion, G., ... and Vamerali, T. 2020. Effects of seed-applied biofertilizers on rhizosphere biodiversity and growth of common wheat (Triticum aestivum L.) in the Field. Frontiers in Plant Sci., 11: 72.

Esmailpour, A., Hassanzadehdelouei, M. and Madani, A. 2013. Impact of Livestock Manure, Nitrogen and Biofertilizer (Azotobacter) on Yield and Yield Components Wheat (Triticum Aestioum L.). Cercetari Agronomice in Moldova., 46(2): 5-15.

Fukami, J., Cerezini, P. and Hungria, M. 2018. Azospirillum: benefits that go far beyond biological nitrogen fixation. AMB Express, 8(73): 1-12.

Itelima, J.U., Bang, W.J., Onyimba, I.A. and Oj, E. 2018. A review: biofertilizer; a key player in enhancing soil fertility and crop productivity. J. Microbiol. Biotechnol. Rep., 2(1): 22-28.

Karthikeyan, N., Prasanna, R., Nain, L. and Kaushik, B. D. 2007. Evaluating the potential of plant growth promoting cyanobacteria as inoculants for wheat. Eur. J. Soil Biol., 43: 23-30.

Kumar, A., Maurya, B.R., Raghuwanshi, R., Meena, V.S. and Islam, M.T. 2017. Co-inoculation with Enterobacter and Rhizobacteria on yield and nutrient uptake by wheat (Triticum aestivum L.) in the alluvial soil under indogangetic plain of India. J. Plant Growth Regulation, 36(3): 608-617.

Mahmoud, A.A. and Mohamed, H.F. 2008. Impact of biofertilizers application on improving wheat (Triticum aestivum L.) resistance to salinity. Res. J. Agri. Biological Sci., 4(5): 520-528.

Manjhi, B.K., Pal, S., Meena, S.K., Yadav, R.S., Farooqui, A., Singh, H.B. and Rakshit, A. 2016. Mycorrhizoremediation of Nickel and Cadmium: A Promising Technology. Nature Environ. Pollution Tech., 15(2): 647-652.

Meena, S.K., Rakshit, A. and Meena, V.S. 2016. Effect of seed bio-priming and $\mathrm{N}$ doses under varied soil type on nitrogen use efficiency (NUE) of wheat (Triticum aestivum L.) under greenhouse conditions. Biocat. Agril. Biotech., 6: 68-75.

Meena, S.K., Rakshit, A. Singh, H.B. and Meena, V.S. 2017. Effect of nitrogen levels and seed bio-priming on root infection, growth and yield attributes of wheat in varied soil type. Biocat. Agril. Biotech., 7: 172-178.

Mohammadi, K. and Sohrabi, Y. 2012. Bacterial biofertilizers for sustainable crop production: a review. ARPN J. Agric. Biol. Sci., 7(5): 307-316.

Mon, J., Bronson, K.F., Hunsaker, D.J., Thorp, K.R., White, J.W. and French, A.N. 2016. Interactive effects of nitrogen fertilization and irrigation on grain yield, canopy temperature, and nitrogen use efficiency in overhead sprinkler-irrigated durum wheat. Field Crops Res., 191: 54-65.

Murumkar, D.R., Nalawade, S.V., Indi, D.V. and Pawar, S.M. 2017. Response of sugarcane seed plot to microbial inoculation by Gluconacetobacter diazotrophicus and phosphate-solubilizing bacteria. Sugar Tech., 19(1): 26-32. 
Parihar, M. and Rakshit, A. 2016. Arbuscular Mycorrhiza: A versatile component for alleviation of salt stress. Nat. Env. Poll. Tech., 15(2): 417-428.

Parihar, M., Meena, V.S., Mishra, P.K., Rakshit, A., Choudhary, M., Yadav, R.P., Rana, K. and Bisht, J.K. 2019. Arbuscular mycorrhiza: a viable strategy for soil nutrient loss reduction. Archiv. Microb., 201(6): 723-735.

Parihar, M., Rakshit, A., Rana, K., Tiwari, G. and Jatav, S.S. 2020b. Arbuscular mycorrhizal fungi mediated salt tolerance by regulating antioxidant enzyme system, photosynthetic pathways and ionic equilibrium in pea (Pisum sativum L.) 2020. Biologia Futura https://doi.org/10.1007/s42977020-00037-1.

Parihar, M., Rakshit, A., Rana, K., Meena, R.P. and Joshi, D.C. 2020a. A consortium of Arbuscular mycorrizal fungi improves nutrient uptake, biochemical response, nodulation and growth of the pea (Pisum satioum L.) under salt stress Rhizosphere, Vol. 15, 100235

Parihar, M. and Rakshit, A. 2016. Arbuscular mycorrhiza: A Versatile Component for Alleviation of Salt Stress, Nat. Environ. Pol. Tech., 15(2): 417-428.

Prasad, A.A. and Babu, S. 2017. Compatibility of Azospirillum brasilense and Pseudomonas fluorescens in growth promotion of groundnut (Arachis hypogea L.). Anais da Academia Brasileira de Ciências, 89(2): 1027-1040.

Rakshit, A., Pal, S., Meena, S., Manjhee, B., Rai, S., Rai, A. and Bhowmick, M.K. 2014. Seed bio-priming: a potential tool in integrated resource management. SATSA Mukhaptra Annual Technical Issue, 18: 94-103.

Sarkar, D., Kar, S.K., Chattopadhyay, A., Rakshit, A., Tripathi, V.K., Dubey, P.K. and Abhilash, P.C. 2020. Low input sustainable agriculture: A viable climate-smart option for boosting food production in a warming world. Ecological Indicators, 115: 106412.
Sivasakthivelan, P. and Saranraj, P. 2013. Azospirillum and its formulations: A Review. Int. J. Microbiolo. Res., 4(3): 275-287.

Subhashini, D.V. 2015. Growth promotion and increased potassium uptake of tobacco by potassium-mobilizing bacterium Frateuria aurantia grown at different potassium levels in vertisols. Comm. Soil Sci. Plant Analy., 46(2): 210-220.

Vaishnav, A., Jain, S., Kasotia, A., Kumari, S., Gaur, R.K. and Choudhary, D.K. 2014. Molecular mechanism of benign microbe-elicited alleviation of biotic and abiotic stresses for plants. In Approaches to Plant Stress and their Management (pp. 281-295). Springer, New Delhi.

Wani, S.A., Chand, S., Wani, M.A., Ramzan, M. and Hakeem, K.R. 2016. Azotobacter :-a potential biofertilizer in agriculture: an overview. In Soil Science: Agricultural and Environmental Prospectives (pp. 333-348). Springer, Cham.

Wu, S.C., Cao, Z.H., Li, Z.G., Cheung, K.C. and Wong, M.H. 2005. Effects of biofertilizer containing N-fixer, P and K solubilizers and AM fungi on maize growth: a greenhouse trial. Geoderma, 125(1-2): 155-166.

Xiao, G., Zhao, Z., Liang, L., Meng, F., Wu, W. and Guo, Y. 2019. Improving nitrogen and water use efficiency in a wheat-maize rotation system in the North China Plain using optimized farming practices. Agric. Water Manag., 212: 172-180.

Zhang, W., Yu, Y., Li, T., Sun, W. and Huang, Y. 2014. Net greenhouse gas balance in China's croplands over the last three decades and its mitigation potential. Environ. Sci. Technol., 48: 2589-2597. 
